\title{
Budidaya Abalon di Asia: Teknologi dan Manajemen Budidayanya
}

\author{
[Abalone Aquaculture In Asia: Its Technology And Aquaculture Management]
}

\author{
Kurniati Umrah Nur \\ Program Studi Budidaya Perairan, Fakultas Ilmu Kelautan dan Perikanan Universitas Hasanuddin \\ J1. Perintis Kemerdekaan KM 10, Tamalanrea, Makassar, Indonesia \\ Email korespondensi: kurniatiumrah@unhas.ac.id
}

\begin{abstract}
ABSTRAK
Abalon merupakan salah satu produk makanan dari laut yang paling mahal. Abalon banyak dibudidayakan di beberapa negara, namun industri budidaya abalon di Asia merupakan yang terbesar di dunia, dengan Tiongkok dan Korea Selatan sebagai dua negara penghasil abalon terbesar di dunia. Secara umum, terdapat dua sistem budidaya yang dikembangkan di Asia yaitu land-based dan sea-based, dengan beberapa inovasi dan penyesuaian untuk menghasilkan abalon yang berkualitas dan bernilai jual tinggi. Benih abalon biasanya dipelihara di kolam-kolam pemeliharaan yang telah dilengkapi oleh lembaran plastik bergelombang, plastik polythene, pipa PVC maupun genteng tanah liat, yang telah ditumbuhi lapisan diatom sebagai sumber makanan bagi larva yang menempel. Pada tahap pembesaran, Korea Selatan dan Tiongkok hanya menggunakan rumput laut sebagai pakan bagi abalon, sedangkan Filipina dan Indonesia, selain pakan alami berupa rumput laut, kedua negara juga sedang mengembangkan pakan buatan yang dapat memberikan pertumbuhan yang signifikan bagi abalon budidaya.
\end{abstract}

Kata Kunci : Budidaya abalon, Industri abalon, manajemen benih, manajemen induk, teknologi budidaya.

\section{ABSTRACT}

Abalone is one of the most expensive seafood products. Abalone is widely cultivated in several countries, but the abalone aquaculture industry in Asia is the largest abalone aquaculture industry in the world, with China and South Korea as the two largest abalone producer around the world. Generally, there are two cultivation systems developed in Asia, namely landbased and sea-based, with several innovations and adjusment to produce high-quality and high-value abalone. Abalone larvae are usually reared in rearing ponds that have been equipped with corrugated plastic plates, polythene plastic, PVC pipes or curved clay blocks, which have been coated with a layer of diatoms as a food supply for the settled larvae. During the grow-out phase, South Korea and China only use seaweed as food for abalone, while the Philippines and Indonesia, in addition to natural food in the form of seaweed, these countries are also developing artificial feed that can provide significant growth for cultured abalone.

Keywords : Abalone aquaculture, abalone industry, larvae management, broodstock management, culture technology.

\section{PENDAHULUAN}

Abalon adalah salah satu makanan dari laut yang bernilai ekonomis tinggi, dan saat ini lebih dari $95 \%$ dari total abalon yang ada di pasaran berasal dari hasil budidaya (FAO, 2017). Dibandingkan dengan Eropa, budidaya abalon di Asia adalah sebuah industri yang besar, dengan Tiongkok dan Korea Selatan sebagai dua negara pengekspor terbesar abalon di dunia, disebabkan oleh meningkatnya jumlah budidaya abalon di kedua negara tersebut sejak 2013-2014 (Cook, 2014).

Tiongkok adalah produsen terbesar abalon di dunia, diikuti oleh Korea Selatan dan Australia. Tiongkok memproduksi 127 ribu ton di tahun 2015 , dengan $90 \%$ produksi abalonnya diperuntukkan bagi konsumsi dalam negeri, menjadikan mereka negara dengan tingkat konsumsi abalon terbesar di dunia. Korea
Selatan adalah produsen abalon terbesar kedua, dengan total produksi sebesar 9 ribu ton pada tahun 2015. Australia menempati urutan ketiga produsen abalon di dunia, menghasilkan sekitar 4500 ton abalon sepanjang tahun 2015. (FAO, 2017). Pada tahun 2017, terjadi peningkatan produksi abalon pada beberapa negara di Asia (Cook, 2019). Data mengenai produksi abalon di negara-negara Asia hingga tahun 2017 dapat dilihat pada Tabel 1 .

Tabel 1. Data Produksi Abalon Negara-Negara Asia Tahun 2017 (Cook, 2019)

\begin{tabular}{|l|c|}
\hline \multicolumn{1}{|c|}{ Negara } & Volume Produksi (mt) \\
\hline Tiongkok & 139.697 \\
\hline Korea Selatan & 16.042 \\
\hline Taiwan & 300 \\
\hline Thailand & 8 \\
\hline Filipina & 5 \\
\hline
\end{tabular}


Ketika Korea telah memulai memproduksi benih abalon pada tahun 1974 (Park \& Kim, 2013), orang-orang Cina baru mulai membudidayakan abalon sejak tahun 1980an (Zhang, Que, Liu, \& Xu, 2004), sedangkan Thailand dan Filipina baru memulai usaha membudidayakan abalon Haliotis asinina pada tahun 1990an (Chalermwat, Szuster, \& Flaherty, 2003; Fermin, 2001). Sebuah program restorasi berbasis budidaya untuk stok alami abalon di Vietnam telah dilakukan sejak tahun 2012 hingga 2015, dan telah direkomendasikan keberlanjutnannya seiring meningkatnya pendapatan nelayan di daerah tersebut. (Chieu, Phuong, Duy, Tuan, \& Thoa, 2017).

Produksi abalon di Indonesia masih didominasi oleh hasil tangkapan alam hingga tahun 2000an. Hasil perikanan tangkap abalon di beberapa daerah di Indonesia seperti Sumbawa, Lombok, Madura, serta Kepulauan Seribu DKI memberikan pendapatan yang cukup baik bagi para nelayan, namun secara perlahan mengalami penurunan baik secara kualitas maupun kuantitas. Nelayan di Lombok bagian selatan mengalami penurunan yang cukup signifikan sejak pertama kali aktifitas penangkapan siput laut ini dilakukan pada tahun 1980an. Nelayan-nelayan di Lombok bagian selatan dapat menangkap abalon sebanyak $300 \mathrm{~kg}$, menurun menjadi $200 \mathrm{~kg}$ pada tahun 1990an, dan menurun secara drastis hingga kurang dari $100 \mathrm{~kg}$ sejak tahun 2000an (Setyono, 2010). Volume ekspor abalon Indonesia (diwakili oleh NTB) ke Hongkong sebanyak 5.2 ton pada tahun 2005, dan menurun menjadi 3.6 pada tahun 2006 (ACIAR, 2007). Budidaya abalon di Indonesia belum berkembang menjadi industri yang mapan, sehingga data mengenai jumlah produksi abalon dari sektor budidaya sangat sulit diketahui, karena jumlahnya yang sangat kecil dan belum berkembang secara signifikan, sedangkan tangkapan dari alam pun terus menurun secara drastis hingga menyebabkan abalon sangat sulit ditemukan di perairanperairan Indonesia.

Merespon menurunnya jumlah tangkapan alam, usaha membudidayakan abalon di Indonesia dimulai sejak tahun 2000an, dengan beberapa pusat-pusat riset milik pemerintah menginisiasi usaha pembenihan abalon dengan mengambil indukan dari alam. Beberapa instansi pemerintah yang aktif mengembangkan teknologi budidaya abalon khususnya pembenihan dan pendederan adalah Balai Besar Riset Budidaya Laut dan Penyuluhan Perikanan di Gondol, Bali, Balai Budidaya Laut Sekotong, Lombok Barat, serta Balai Bioindustri Laut LIPI di Lombok Utara.

Terdapat tiga spesies utama abalon yang dibudidayakan secara komersil di negaranegara Asia seperti Cina, Korea Selatan, Thailand, Filipina dan Vietnam. Ketiganya adalah Pacific abalon $H$. discus hannai, small abalon $H$. diversicolor supertexta dan donkey's ear abalon $H$. asinina. Semua spesies komersil ini dibudidayakan menggunakan metode dan teknologi budidaya yang berbeda, dan diberi pakan buatan atau alami.

Kajian ini membahas tentang budidaya abalon pada beberapa negara Asia, seperti Tiongkok, Korea Selatan, Thailand, Filipina dan Indonesia. Sebelumnya, penulis juga pernah melakukan penelitian tentang kecernanan protein pada spesies abalon Australia (Nur, Adams, Stone, Savva, \& Adams, 2018). Pembahasan artikel ini mengkaji terhadap beberapa teknologi budidaya yang diterapkan di setiap negara, manajemen induk, pemeliharaan larva, serta pakan abalon yang digunakan. Artikel ini bertujuan untuk memberikan gambaran menyeluruh mengenai budidaya abalon di Asia, sebagai salah satu industri abalon terbesar di dunia.

\section{TEKNOLOGI SISTEM BUDIDAYA}

Para pembudidaya abalon di Korea Selatan menggunakan sistem budidaya air mengalir (land-based raceway) dan kontainer gantung (hanging container) dari tahun 1970an hinggan 1980an. Namun pada tahun 1990an, Korea Selatan mulai mengembangkan metode budidaya menggunakan keramba (sea cage), dan telah dikembangkan menjadi keramba anti gelombang (wave-proof sea cage) pada tahun 2000, dan sejak saat itu, budidaya abalon secara komersil di Korea Selatan meningkat secara signifikan (Park \& Kim, 2013). Wilayah penghasil utama abalon di Korea adalah daerah Wando yang terletak di Provinsi Jeollanamdo. Sistem budidaya terbagi menjadi dua tahapan, pembenihan dan pemeliharaan. Juvenil abalon kemudian dipanen dari keramba di laut setelah dua tahun.

Terdapat dua spesies abalon yang dibudidayakan secara komersil di Tiongkok, yaitu Haliotis discuss hannai dan Haliotis 
Media Akuatika : Jurnal Ilmiah Jurusan Budidaya Perairan. 2020. 5(3): 95-106.

diversicolor. Budidaya abalon $H$. discuss hannai secara intensif berpusat di bagian utara Tiongkok, dengan mayoritas produksi berpusat di daerah Dalian dan Shandong. Sedangkan $H$. diversicolor intensif dibudidayakan di daerah Tiongkok bagian selatan, di daerah Fujian dan Guangdong Timur. Sistem budidaya yang digunakan secara luas di Tiongkok terdiri dari tiga jenis, yaitu land-based (kolam-kolam di darat), suspended longlines cages (keramba apung) dan intertidal ponds (tambak pasang surut) (Zhang et al., 2004). Sistem-sistem tersebut kemudian dikombinasikan dengan berbagai macam metode, shelter atau hides untuk memaksimalkan ruang pemeliharaan dan pembesaran juvenil abalon, juga untuk menjaga juvenil abalon tersebut dari serangan predator, terutama jika menggunakan keramba apung atau kolam-kolam di daerah pasang surut. Beberapa yang umum digunakan adalah seng plastik bergelombang atau genteng tanah liat (Gambar 1) Struktur material tersebut menyediakan ruang bagi abalon untuk menempel dan berlindung di bawahnya atau di antara alur-alur dari seng plastik tersebut.
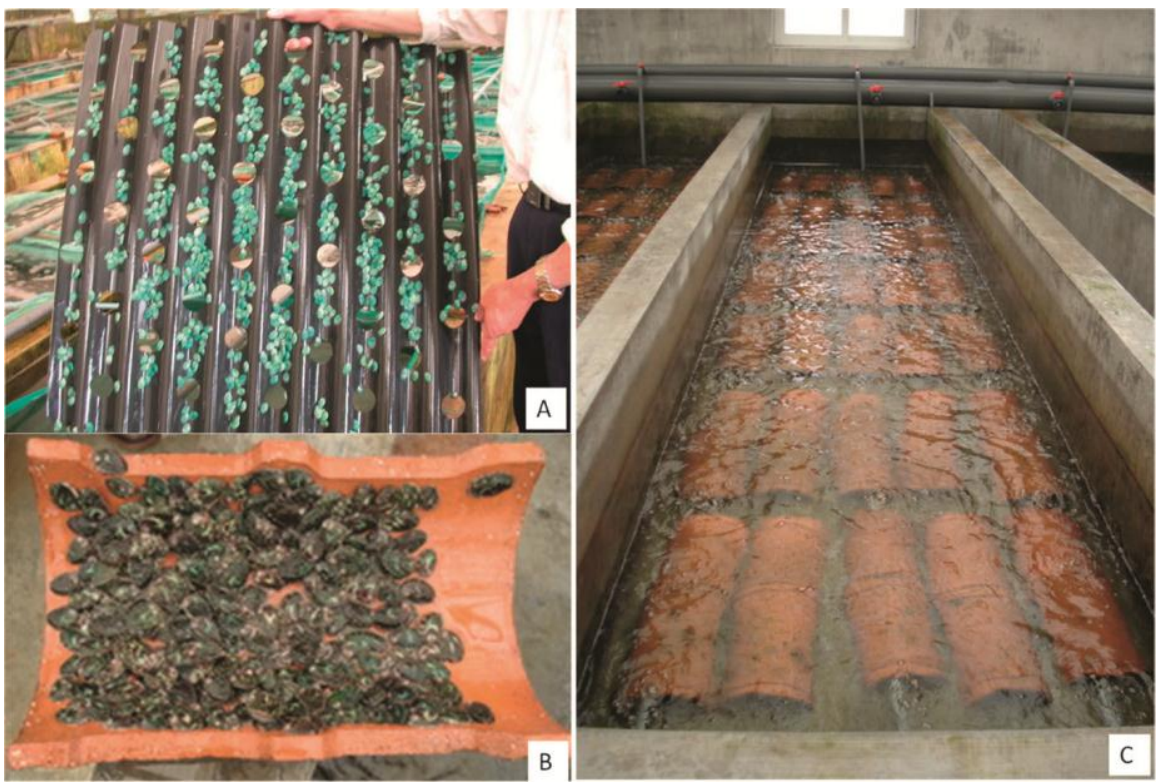

Gambar 1. A. Lembaran seng plastik sebagai media penempelan abalon, B. Genteng tanah liat yang digunakan sebagai media penempelan abalon, C. Genteng tanah liat yang digunakan diletakkan didasar kolam pemeliharaan (Wu \& Zhang, 2016)

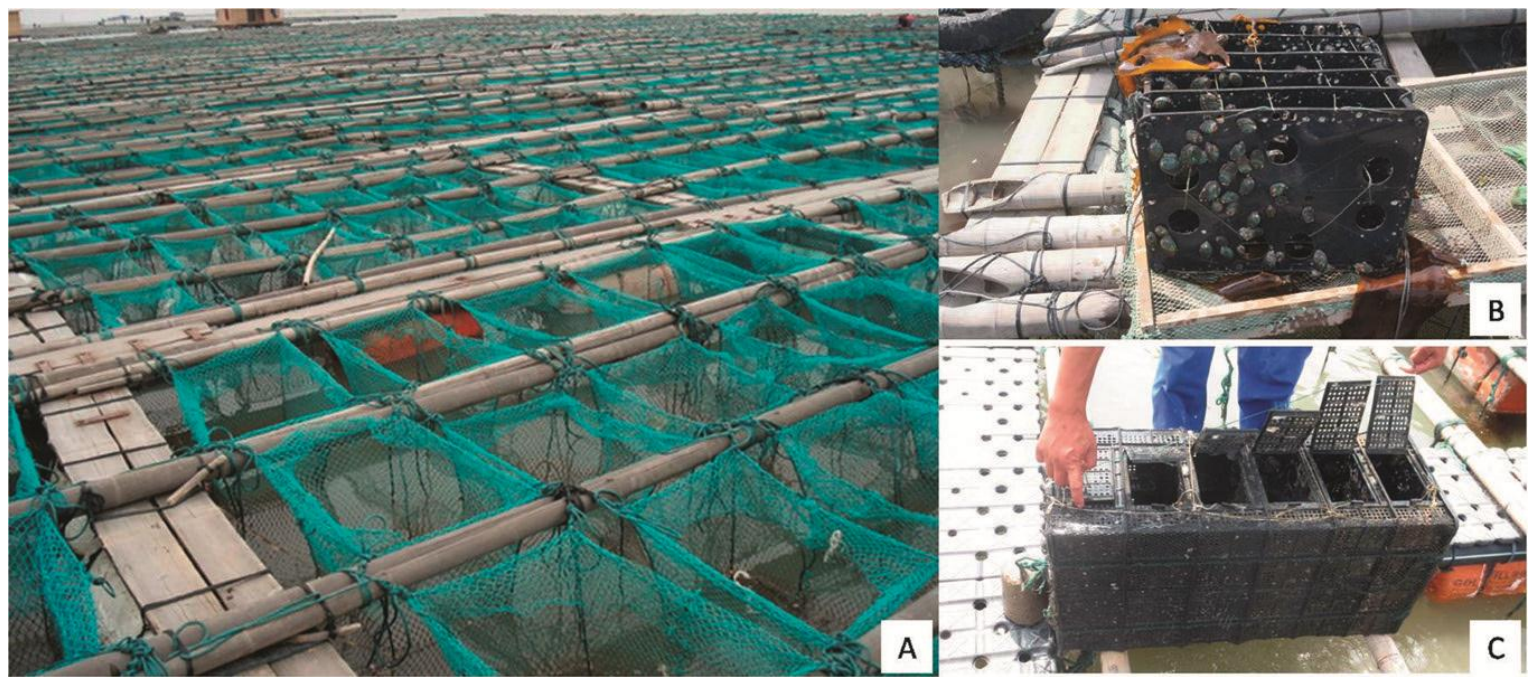

Gambar 2. A. Keramba Jaring Apung untuk pembesaran juvenil abalon yang lazim digunakan oleh pembudidaya abalon di bagian Tiongkok selatan, B. Pelat-pelat plastik sebagai shelter bagi juvenil abalon, C. Keranjang plastik berjenjang yang dapat dibuka dan ditutup sebagai shelter bagi juvenil abalon (Wu \& Zhang, 2016). 


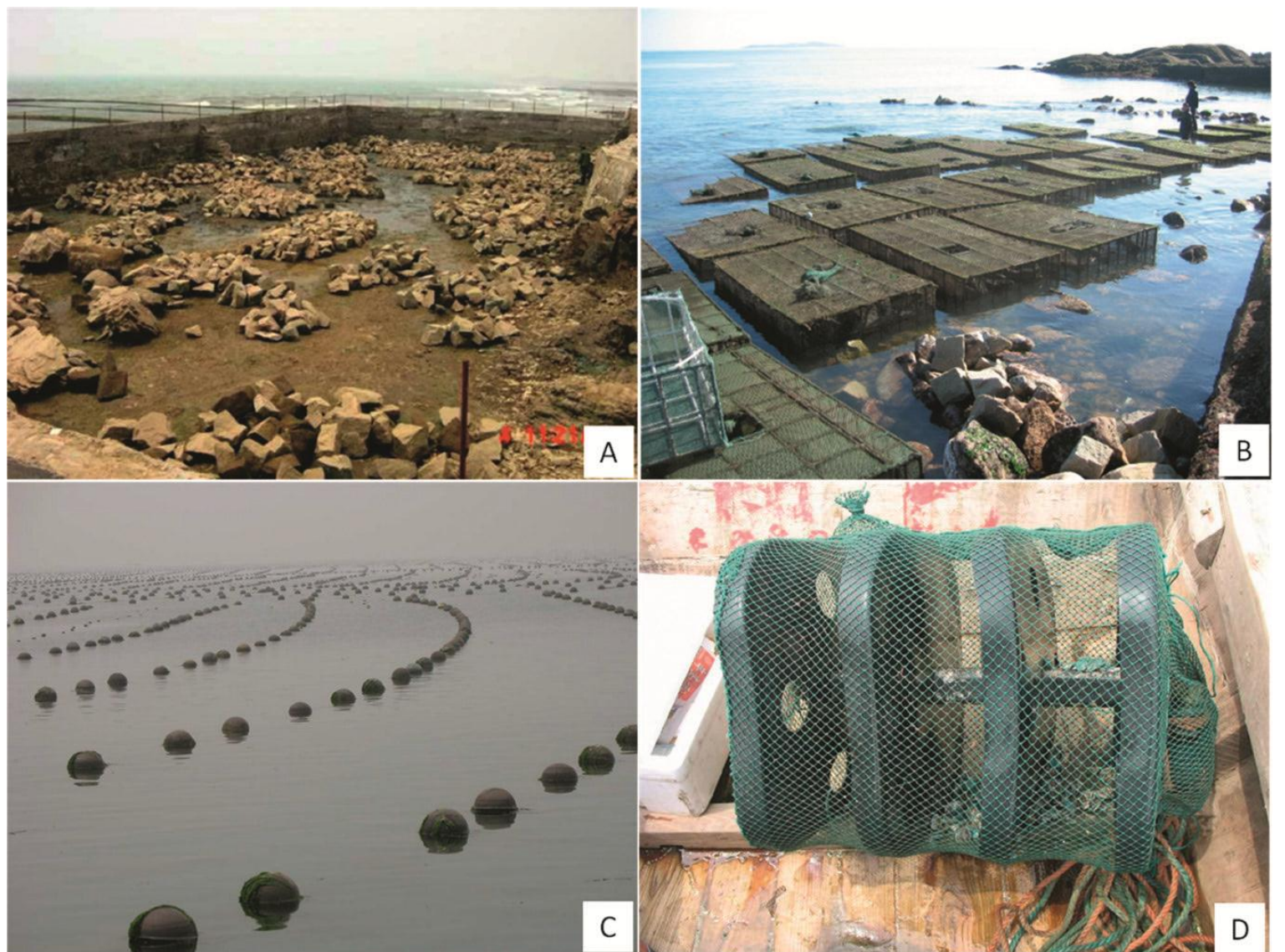

Gambar 3. A. Tambak atau kolam pembesaran abalon di daerah pasang surut (Intertidal ponds), B. Metode kultur dasar perairan (Bottom culture method), C. Keramba Jaring apung longline, D. Shelter yang digunakan pada keramba jaring apung longline (Wu \& Zhang, 2016).

Sistem dan metode di atas digunakan khususnya pada budidaya abalon yang menggunakan sistem land-based. Sedangkan untuk budidaya abalon yang menggunakan keramba apung, longline maupun kolamkolam pada daerah intertidal, pembudidaya abalon di Tiongkok bagian utara dan Tiongkok bagian selatan, menggunakan metode dan alat (device) yang berbeda pada proses pembesaran abalon mereka. Budidaya abalon di bagian selatan Tiongkok menggunakan keramba jaring apung untuk pembesaran abalon. Keramba tersebut terbagi menjadi ratusan kotak-kotak yang terbuat dari jaring yang digantungkan di antara kerangka-kerangka bambu. Sebagian besar dari bagian petak jaring tersebut berada dibawah air. Fasilitas ini kemudian dikombinasikan dengan beberapa alat (device) yang berfungsi sebagai media penempelan atau shelter bagi juvenil abalon. Beberapa diantaranya adalah rak-rak yang dibuat dari pelat plastik yang digunakan sebagai shelter bagi juvenil abalon (Gambar 2). Rak-rak plastik ini kemudian ditempatkan pada jaring- jaring apung pada keramba jaring apung dilaut. Alat lain yang digunakan adalah keranjang plastik dengan bagian yang berjenjang didalamnya, biasanya sebanyak 6 jenjang, digunakan sebagai shelter untuk juvenil abalon (Wu \& Zhang, 2016). Keranjang plastik berjenjang memiliki tingkat keamanan yang lebih bagus, karena sistem yang tertutup menyebabkan juvenil abalon tidak bisa merayap keluar dari keranjang tersebut, sekaligus mencegah predator seperti burungburung laut untuk memakan juvenil abalon tersebut.

Berbeda dengan budidaya abalon di Tiongkok bagian selatan, budidaya abalon di Tiongkok utara menggunakan tiga sistem budidaya yaitu kolam atau tambak didaerah pasang surut di Qingdao, keramba jaring apung long-line di Rongcheng, serta metode kultur dasar perairan (bottom culture method) di Changhai, Dalian (Gambar 3). Pada sistem budidaya yang menggunakan kolam atau tambak-tambak di daerah pasang surut, pemilihan lokasi yang tepat dan kepadatan 
juvenil abalon menjadi faktor yang sangat krusial. Pada sistem budidaya ini, abalon tidak diberi pakan buatan, tetapi diberi makan pakan alami rumput laut, yang ditumbuhkan secara alami pada tambak-tambak tersebut, sehingga perairan yang bersih dan visibilitas perairan yang bagus menjadi penting, agar rumput laut dapat tumbuh secara alami dan menyediakan makanan yang cukup bagi juvenil abalon tersebut. Kepadatan yang disarankan adalah 2025 ekor $/ \mathrm{m}^{2}$ dengan rata-rata panjang cangkang (Shell Length, SL) adalah 4.0-4.5 cm. Sedangkan pada metode longline, perawatan secara berkala untuk menghilangkan biofuling seperti tiram dan tunicata sangatlah penting. Selain itu jaring-jaring yang digunakan biasanya diganti sebanyak empat kali hingga masa panen tiba (Wu \& Zhang, 2016).

Metode budidaya abalon yang berbasis di laut (sea-based) dan berbasis daratan (landbased) memiliki kekurangan dan kelebihannya masing-masing. Biaya produksi metode berbasis di laut sangat rendah jika dibandingkan dengan metode budidaya berbasis daratan, terutama jika dibandingkan dengan metode RAS tertutup. Metode RAS tertutup memiliki biaya produksi yang paling tinggi dibandingkan metode lainnya. Sedangkan dari sisi keamanan fasilitas budidaya, metode sea-based sangat rentan terhadap bencana alam terutama angin puting beliung, seperti yang dialami oleh pembudidaya abalon di Korea Selatan setiap tahun. Metode ini juga sangat rentan terhadap predator alami abalon seperti anjing laut, dan juga rentan terhadap perburuan (poaching). Metode land-based memiliki keuntungan dari aspek keamanan dari bencana alam, kecuali bencana alam berupa gempa bumi dan tanah longsor, juga aman dari predator alami dan perburuan. Namun, pada sistem RAS tertutup, masuknya penyakit kedalam sistem bisa sangat fatal akibatnya bagi budidaya abalon, karena sistem ini seperti inkubator bagi mikroorganisme. Karena itu sangatlah penting untuk mencegah masuknya patogen kedalam sistem (Koizumi \& Tsuji, 2017).

Perkembangan teknologi budidaya abalon di Thailand, Vietnam, Filipina dan Indonesia tidak sesignifikan perkembangan budidaya siput laut ini di Tiongkok dan Korea Selatan. Budidaya abalon di Thailand selama ini menggunakan sistem land-based dan onshore untuk pembesaran abalon. Meskipun tambak-tambak pada zona intertidal merupakan sistem yang paling baik untuk diterapkan dalam proses pembesaran abalon, namun hal tersebut tidak dapat dilakukan mengingat zona intertidal adalah ruang publik, sehingga penggunaannya akan berbenturan dengan peraturan pemerintah setempat mengenai pemanfaatan ruang publik untuk tujuan komersil (Padermsak Jarayabhand \& Paphavasit, 1996)

Budidaya abalon di Filipina merupakan industri yang sedang berkembang, dengan memfokuskan pengembangannya pada satu spesies abalon tropis Haliotis asinina. Budidaya abalon di Filipina menggunakan tehnik yang dikembangkan oleh Jepang, yaitu menggunakan pipa PVC sebagai media penempelan juvenil abalon (Fermin, 2001). Sedangkan sistem budidaya yang digunakan adalah land-based menggunakan tangki-tangki dengan sistem air mengalir (flow-through) yang terbuat dari fiber dan keramba apung di laut .

Teknologi budidaya abalon di Indonesia telah dikembangkan oleh Balai Besar Riset Budidaya Laut dan Penyuluhan Perikanan (BBRBLPP), Gondol Bali sejak tahun 2007 hingga sekarang (Rusdi et al., 2020). Selain BBRBLPP, beberapa balai riset milik pemerintah seperti Balai Budidaya Laut Sekotong di Lombok Barat dan Balai Bioindustri Laut milik Lembaga Ilmu Pengetahuan Indonesia (LIPI) di Lombok Utara juga telah mengembangkan metode budidaya abalon sejak awal tahun 2000an. Teknologi yang digunakan sebenarnya hampir menyerupai teknologi budidaya yang digunakan di beberapa negara asia lainnya seperti Tiongkok dan Korea Selatan, yaitu keramba jaring apung (floating sea cages) dan atau sistem land-based. Hanya saja, minat masyarakat luas terhadap pembesaran abalon masih sangat rendah, sehingga industri budidaya abalon di Indonesia belum bisa menjadi sebesar industri budidaya abalon di Tiongkok ataupun Korea Selatan. Hal ini dikarenakan, durasi pembesaran abalon tropis $H$. asinina yang cukup lama, antara 7-8 bulan sebelum bisa dipanen dan dijual (Rusdi et al., 2020).

\section{MANAJEMEN INDUK}

Induk abalon yang berkualitas sangat penting dalam kesuksesan budidaya abalon, karena induk yang berkualitas akan menghasilkan telur yang berkualitas, benih 
yang tahan terhadap penyakit, dengan tingkat kelangsungan hidup yang tinggi.

Korea memiliki kurang lebih 500 hatcheri (panti benih) berskala kecil, yang menyediakan benih berkualitas untuk keperluan industri abalon komersil. Pada hatcherihatcheri tersebut, benih diproduksi setiap pertengahan april setiap tahun. Hatcheri dilengkapi dengan fasilitas untuk inkubasi dalam rangka mengkondisikan induk abalon sebelum memijah. Untuk mengkondisikan induk abalon, kontrol akumulasi temperature secara efektif digunakan secara luas. Induk abalon diberi makan rumput laut Laminaria japonica dan Undaria pinnatifida. Induk abalon yang telah matang gonad distimulasi agar memijah. Metode stimulasi yang digunakan adalah thermal shock, dimana induk abalon dibiarkan terpapar oleh udara dan suhu yang cukup tinggi, lalu kemudian dimasukkan kedalam air laut yang telah disinari dengan UV. Proses induksi tidak dilakukan secara bersamaan. Induk jantan biasanya diinduksi 1 hingga 2 jam setelah induk betina diinduksi. Hal ini karena jika mereka diinduksi secara bersamaan, induk jantan akan memijah lebih dahulu sebelum induk betina memijah (Park \& Kim, 2013)

Sedangkan di Tiongkok, induk abalon memijah pada dua waktu atau musim yang berbeda tergantung pada lokasi budidayanya. Di Tiongkok bagian selatan, induk abalon biasanya memijah dan menghasilkan benih pada temperatur air yang sama dengan temperatur lingkungan perairan sekitarnya (ambient temperature), dan memijah pada akhir musim gugur. Sedangkan di bagian utara, induk abalon memijah dan menghasilkan telur dengan temperatur air yang dipanaskan selama awal musim semi. Metode induksi yang digunakan adalah kombinasi dari eksposure pada udara dan perendaman pada air laut yang suhunya dinaikkan dan menggunakan radiasi UV, seperti metode yang dikembangkan oleh Uki \& Kikuchi (1984). Namun beberapa panti benih (hatcheri) di Tiongkok bagian selatan menggunakan hidrogen peroxida sebagai metode induksi pemijahan bagi $H$. diversicolor (Zhang et al., 2004)

Pemilihan abalon tropis H.asinina memberikan keuntungan tersendiri saat menjadi komoditas budidaya seperti yang dikembangkan di Thailand. Jika spesies abalon $H$. discuss hannai dan $H$. diversicolor yang dikembangkan di Tiongkok dan Korea Selatan hanya memijah sekali dalam setahun, maka spesies abalon tropis $H$. asinina dapat memijah sepanjang tahun, dengan puncak musim memijah dari September hingga Maret setiap tahunnya (Padermsak \& Paphavasit, 1996). Hal ini kemudian berimplikasi pada ketersediaan stok benih abalon sepanjang tahun, yang memungkinkan masa panen bisa dilakukan hampir sepanjang tahun. Karena itu, sangatlah penting untuk mendapatkan induk abalon yang matang gonad sepanjang tahun, dan hal ini hanya akan diperoleh dengan memastikan bahwa induk abalon berada pada lingkungan pemeliharaan yang optimal dan diberi pakan yang memiliki kandungan nutrisi yang seimbang.

Beberapa metode induksi abalon sebagai usaha untuk menstimulasi pemijahan abalon tropis telah di terapkan oleh Jarayabhand et.al (1995), termasuk diantaranya thermal shock, penggunaan hydrogen peroxida, serta penyinaran UV. Namun diantara ketiga metode induksi tersebut, penyinaran air laut dengan sinar UV merupakan metode yang paling sering digunakan terutama dalam skala laboratorium. Namun, pemijahan secara natural merupakan proses pemijahan yang terbaik dan hal ini sangat dimungkinkan jika induk abalon dalam kondisi matang gonad dengan lingkungan yang optimum dan nutrisi yang cukup.

Induk abalon tropis $H$. asinina untuk keperluan pembenihan di Filipina, diperoleh baik dari alam maupun induk hasil pembenihan di hatcheri yang dibesarkan dan disiapkan sebagai induk (Fermin, 2001). Induk abalon tropis $H$. asinina memijah sepanjang tahun dan memijah secara spontan tanpa induksi apapun.

Di Indonesia, kuantitas induk abalon tropis $H$. asinina yang disiapkan untuk pemijahan bergantung pada beberapa faktor, termasuk jumlah benih yang ingin diproduksi. Hal ini karena salah satu faktor penentu keberhasilan usaha pembenihan abalon tropis $H$. asinina adalah jumlah induk yang mencukupi. Tingkat kelulushidupan larva abalon tropis $H$. asinina masih sangat rendah, sehingga untuk menghasilkan benih yang banyak, jumlah induk juga harus banyak dengan frekuensi pemijahan yang terus menerus. Induk abalon di alam mengalami matang gonad pada saat berumur kurang lebih 2 tahun, atau saat mencapai ukuran panjang cangkang sekitar 45-50 mm pada abalon jantan 
dan 50-55 mm pada abalon betina. Sehingga induk yang akan dipilih untuk memijah adalah induk yang masih muda, yang berumur sekitar 2-3 tahun (Setyono, 2010). Metode-metode induksi yang digunakan untuk menstimulasi pemijahan adalah metode yang juga umum digunakan di negara lain, termasuk desikasi, penggunaan hidrogen peroksida, aerasi yang kuat, kejutan suhu (thermal shock) dan penyinaran UV (Setyono, 2010).

\section{MANAJEMEN BENIH}

Setelah telur menetas menjadi larva, salah satu hal krusial yang harus diperhatikan adalah proses setlement larva keatas substrat yang cocok. Larva abalon bersifat lecithotropic, yaitu larva yang masih membawa yolk sac (kantung kuning telur) sebagai cadangan makanan di awal-awal kehidupannya sebagai larva, sebelum menempel pada substrat yang cocok dan memulai kehidupannya sebagai hewan bentik (Setyono, 2010).

Panti benih (hatcheri) di Korea Selatan menempatkan larva trocopore pada suhu 15$16^{0} \mathrm{C}$, suhu normal air laut di kawasan tersebut di bulan Mei. Larva akan siap untuk menempel ke substrat 120 jam setelah fertilisasi atau sekitar 5 hari setelah fertilisasi. Larva akan menempel pada substrat yang terbuat dari lembaran plastik transparan berukuran 30x30 $\mathrm{cm}$ dengan ketebalan $0.2-0.3 \mathrm{~mm}$, yang diletakkan didasar kolam pemeliharaan. Lembaran-lembaran plastik tersebut telah dilapisi oleh diatom, yang telah ditumbuhkan di atas lembaran plastik tersebut beberapa minggu sebelum pemijahan. Diatom tersebut menjadi sumber makanan juvenil abalon, selain juga pakan buatan yang diberikan secara berkala (Park \& Kim, 2013).

Pada budidaya abalon di Tiongkok bagian utara, larva veliger dipindahkan ke kolam pemeliharaan 4 hari setelah fertilisasi. Larva yang telah dipindahkan ke kolam pemeliharaan akan siap untuk menempel di hari ke 5 atau 6 setelah fertilisasi pada suhu $20^{\circ} \mathrm{C}$. Untuk mencapai panjang cangkang 3-7 mm SL (Shell Length), dibutuhkan waktu pemeliharaan antara 35-40 hari. Serupa dengan tahap pemeliharaan di Korea Selatan, larva menempel pada lembaran plastik bergelombang berukuran $30 \times 40 \mathrm{~cm}$, yang telah terlapisi dengan diatom Navicula sp sebagai asupan makanan bagi larva abalon, dengan kepadatan antara 100-150 ekor abalon per lembar plastik.
Suhu kolam pemeliharaan juga di tingkatkan, dari suhu ambien perairan $\left(6-10^{\circ} \mathrm{C}\right)$ ke suhu kultur berkisar antara $16-20^{\circ} \mathrm{C}$ (Wu \& Zhang, 2016)

Salah satu waktu yang krusial dalam tahapan pemeliharaan larva abalon adalah masa-masa awal setelah larva menempel ke substrat yang dipenuhi oleh diatom, karena itu, sekitar 7-10 hari setelah larva menempel, larva diberi diatom yang berukuran kecil (2-5 um), sedangkan diatom yang berukuran lebih besar diberikan setelah 10 hari untuk pertumbuhan yang maksimal, agar mencapai panjang cangkang 3-7 $\mathrm{mm}$. Selain diatom, larva abalon juga telah diberikan pakan buatan untuk mendukung pertumbuhannya. Laju metamorfosis larva abalon di Tiongkok bagian utara berkisar antara 20\%-50\%, sedangkan tingkat kelangsungan hidup larva abalon mulai dari tahap penempelan hingga akhir masa pemeliharaan cukup tinggi, berkisar antara 70\%-90\% (Wu \& Zhang, 2016).

Manajemen yang cukup berbeda diterapkan oleh pembudidaya abalon di Tiongkok bagian selatan. Pembudidaya abalon di daerah ini tidak memiliki fasilitas penyaringan air yang memadai, sehingga supply air laut untuk keperluan budidaya dialirkan dari sumur pasir sedalam 60 meter. Sebelum larva menempel,membran plastik yang terbuat dari polythene berkuran $1 \mathrm{x} 1 \mathrm{~m}$ untuk penempelan dibilas dengan air mengalir untuk menghilangkan lapisan diatom yang telah lama, yang tidak cocok untuk larva yang baru menempel, lalu dimasukkan kedalam kolam pemeliharaan yang telah berisi larva yang siap menempel. Penggunaan membran plastik terbukti memberikan tingkat kelulushidupan larva yang signifikan saat proses penempelan dan setelah proses penempelan (Zhang et al., 2004).

Jika pembudidaya abalon di Tiongkok bagian utara menggunakan diatom Navicula $s p$ sebagai makanan bagi larva yang menempel, maka di Tiongkok bagian selatan, pembudidaya menggunakan Cocconeis spp sebagai makanan bagi larva abalon. Sebelum larva menempel, kolam pemeliharaan diaerasi dengan tanpa pergantian air, dengan suhu normal perairan antara $23-25^{\circ} \mathrm{C}$, lebih tinggi daripada suhu kolam pemeliharaan abalon di Tiongkok bagian utara. Kepadatan larva abalon juga jauh lebih tinggi, yaitu sekitar 500-1000 ekor abalon per membran plastik. Namun hal ini mungkin 
disebabkan karena luas permukaan membran plastik yang digunakan juga lebih luas dari membran plastik yang digunakan para pembudidaya di Tiongkok bagian utara. Panjang cangkang yang diperoleh setelah tahap pemeliharaan selesai adalah 2-5 $\mathrm{mm}$, lebih kecil daripada abalon yang dipelihara di Tiongkok bagian utara (Wu \& Zhang, 2016).

Pada panti benih di Filipina, larva abalon tropis $H$. asinina yang telah siap untuk menempel ditempatkan pada tangki-tangki penempelan, dengan aliran air yang statis, kepadatan 500 larva per liter, menggunakan pipa PVC bergelombang yang digantung didalam tangki-tangki sebagai media penempelan. Diatom Cocconeis spp dan Navicula $s p$ digunakan sebagai makanan bagi larva abalon tropis.

Serupa dengan perlakuan pada larva abalon tropis $H$. asinina di Filipina, larva abalon tropis yang ada di Indonesia dipelihara di bak-bak pemeliharaan yang telah dilengkapi oleh lembaran seng plastik bergelombang sebagai media penempelan. Lembaranlembaran seng plastik tersebut telah ditumbuhi oleh diatom, utuk menjamin ketersediaan makanan bagi larva abalon tersebut. Penggantian air didalam bak pemeliharaan dilakukan setelah larva menempel pada substrat ,minimal dua kali seminggu sebanyak 50\% volume air. Namun setelah juvenil berumur 1 bulan, penggantian air dilakukan setiap hari sebanyak $50 \%$ volume air pada sistem tertutup, sedangkan pada sistem air mengalir, air dibiarkan mengalir secara terus menerus pada volume yang rendah (Setyono, 2010).

\section{PAKAN ABALON}

Pakan abalon pada usaha budidaya berkontribusi sekitar $60-70 \%$ dari total biaya produksi (Du \& Niu, 2003), dan menyediakan pakan yang memenuhi kecukupan nutrisi bagi abalon sangatlah penting untuk mendukung pertumbuhan abalon (Tung \& Alfaro, 2011).

Abalon di habitat alaminya memanfaatkan rumput laut sebagai makanan alaminya. Abalon tropis $H$. asinina di Indonesia memakan rumput laut jenis Laminaria sp (alga coklat), Gracillaria sp (alga merah) dan Ulva sp (alga hijau) sebagai makanan alami mereka di laut (Giri, Marzuqi, Rusdi, \& Andriyanto, 2016). Namun abalon yang dibudidayakan diberi pakan rumput laut dan pakan buatan, baik sebagai pakan kombinasi maupun sebagai pakan tunggal.

Abalon akuakultur di Korea menggunakan pakan buatan dan rumput laut untuk tahapan pertumbuhan yang berbeda. Pada tahap pemeliharaan larva, diatom dan pakan buatan digunakan sebagai asupan bahan makanan bagi juvenil abalon. Pakan buatan yg digunakan merupakan campuran dari rumput laut jenis Laminaria kering (dried kelp)yang dijadikan tepung dan tepung ikan. Selain itu, pakan buatan juga mengandung mikroorganisme (Park \& Kim, 2013). Pakan buatan yang menggunakan tepung rumput laut terbukti memberikan hasil pertumbuhan abalon yang lebih baik, daripada abalon yang hanya diberikan rumput laut saja. Inklusi tepung rumput laut Kelp Eclonia maxima terbukti memberikan pertumbuhan yang lebih cepat dan rasio konversi pakan yang lebih baik pada spesies abalon Afrika Selatan H. midae (Nel et al., 2017).

Sedangkan untuk tahap pembesaran, abalon di Korea Selatan hanya diberi pakan rumput laut dari jenis Laminaria japonica dan Undaria pinnitifida. Pengintegrasian antara budidaya rumput laut dan abalon di Korea menyebabkan suplai rumput laut segar untuk keperluan pakan abalon dapat tersedia sepanjang tahun (Park \& Kim, 2013). Namun, pemberian pakan rumput laut $L$. japonica dan $U$. pinnitifida secara terus menerus dapat menurunkan laju pertumbuhan abalon, jika dibandingkan dengan pakan yang memiliki nutrisi yang seimbang (Bautista-Teruel et.al., 2003; Cho et al., 2006; Garcia-esquivel \& Felbeck, 2009; Jang et al., 2018; Jung et al., 2016; Myung et al., 2016). Hal ini disebabkan karena rumput laut ini tidak dapat memenuhi kebutuhan akan protein (asam amino) dan lemak (asam lemak) dari abalon $H$. discuss hannai (Mai et.al., 1995; Uki et.al., 1985). Karena itu, usaha untuk menggantikan penggunaan rumput laut ini pada pakan abalon, terutama penggunaannya pada pakan buatan giat dilakukan oleh peneliti di Korea Selatan. Salah satu rumput laut yang memberi hasil yang cukup memuaskan sebagai pengganti L.japonica dan $U$. pinnitifida adalah Ulva australis, yang tersedia secara melimpah di alam, dan terkadang menyebabkan masalah polusi pada perairan di negara ini. Abalon yang diberi pakan buatan $60 \%$ tepung rumput laut $U$. australis menunjukkan pertumbuhan yang 
terbaik jika dibandingkan dengan abalon yang diberi pakan U.pinnitifida (Ansary et al., 2019).

Juvenil abalon di Tiongkok pada masa transisi dari fase pemeliharaan ke fase pembesaran, atau ketika beralih dari diatom ke pakan buatan, biasanya diberi pakan berbentuk mikropartirkulat berukuran 15-25 um yang terbuat dari tepung Dunaliella salina, Spirulina spp dan Platymonas cordiformis. Juvenil abalon kemudian diberikan pakan mikropartikulat berukuran lebih besar sekitar 30-40 um yang terbuat dari tepung Laminaria japonica dan Undaria pinnatifida yang diperkaya dengan probiotik (Wu \& Zhang, 2016).

Pada tahap pembesaran, juvenil abalon kemudian hanya diberi pakan makroalga. Laminaria japonica, Undaria pinnatifida atau Ulva pertusa untuk $H$. discuss hannai, dan Gracillaria sp serta Laminaria japonica secara parsial untuk $H$. diversicolor (Zhang et al., 2004). Namun selama musim panas, seiring dengan berakhirnya musim panen kelp, ketersediaan kelp bisa menipis selama 2-3 bulan. Untuk mengatasi hal tersebut, Laminaria yang diasinkan atau dibekukan menjadi pengganti Laminaria yang segar selama berkurangnya ketersediaan Laminaria segar. Baik Laminaria yang diasinkan atau yang dibekukan harus diproses terlebih dahulu sebelum diberikan kepada abalon (Zhang et al., 2004).

Abalon tropis $H$. asinina di Filipina diberi pakan alga merah Gracilariopsis bailinae pada tahap pembesaran (Fermin, 2001). Namun penelitian mengenai pakan alternatif telah banyak dilakukan di Filipina yang menggunakan pakan buatan dengan tepung ikan, tepung udang atau tepung kedelai, casein maupun spirulina sebagai sumber protein utama (Bautista-Teruel et al., 2003; Bautista-teruel, Koshio, \& Ishikawa, 2011; Bautista-teruel \& Millamena, 1999). Pemberian pakan buatan ternyata menghasilkan pertumbuhan yang lebih baik dibandingkan dengan pemberian rumput laut sebagai pakan abalon.

Sedangkan abalon tropis $H$. squamata yang dikembangkan di balai-balai riset milik pemerintah, diberikan pakan Gracillaria sp dan Ulva sp (Setyono, 2010). Penelitian mengenai alternatif pakan bagi budidaya abalon juga telah cukup banyak dilakukan di Indonesia. Diantaranya adalah penelitian mengenai pakan buatan dari tepung rumput laut Gracillaria $s p$ dan Ulva (Giri et al., 2015, 2016; Khotimah et.al., 2018; Marzuqi et.al., 2012).

Pemberian pakan buatan pada abalon budidaya memberikan beberapa keuntungan jika dibandingkan dengan pakan alami, yaitu 1). Pakan buatan dapat mengurangi resiko masuknya patogen, hama dan predator kedalam sistem budidaya, 2) lebih mudah dalam penyimpanan daripada pakan segar, 3) tidak membutuhkan personel yang banyak dalam pengaplikasiannya, 4) rasio konversi pakan yang rendah, sekitar 1.5:1, 5) dapat diproduksi sepanjang tahun, mengurangi resiko kelangkaan pakan jika menggunakan pakan alamiyang hanya bisa tersedia pada waktuwaktu tertentu saja, 6) kandungan nutrisi yang dapat disesuaikan dnegan kebutuhan abalon, dan 7) komposisi nutrisi yang konstan (Hahn, 1989; Mosquiera, 1992; Vandepeer \& van Barneveld, 2005).

\section{KESIMPULAN}

Budidaya abalon merupakan industri yang sangat berkembang terutama di negaranegara Asia. Teknologi budidaya baik dari segi pembenihan, pemeliharaan dan pembesaran telah banyak dikuasai oleh negara-negara seperti Tiongkok dan Korea Selatan, dimana budidaya abalon telah menjadi salah satu industri utama dikedua negara. Sedangkan bagi negara-negara seperti Thailand, Filipina dan juga Indonesia, industri budidaya abalon masih membutuhkan pengembangan yang dan penelitian yang menyeluruh pada beberapa aspek, terutama pada aspek pakan abalon.

\section{DAFTAR PUSTAKA}

ACIAR. (2007). Abalone Industry Enhancement In Eastern Indonesia.

Ansary, M. W. R., Jeong, H. S., Lee, K. W., Kim, P. Y., Kim, J., Yun, A.-Y., ... Kim, T.-I. (2019). Dietary substitution effect of Ulva australis for Undaria pinnatifida on growth, body composition and air exposure of juvenile abalone, Haliotis discus (Reeve 1846). Journal of Applied Phycology, 31(2): 1467-1474. https://doi.org/10.1007/s10811-018-16544

Bautista-Teruel, M. N., Fermin, A. C., \& Koshio, S. S. (2003). Diet development and evaluation for juvenile abalone, Haliotis asinina: Animal and plant protein 
sources. Aquaculture, 219(1-4), 645-653. https://doi.org/10.1016/S0044-

8486(02)00410-6

Bautista-teruel, M. N., Koshio, S. S., \& Ishikawa, M. (2011). Diet development and evaluation for juvenile abalone , Haliotis asinina Linne: Lipid and essential fatty acid levels. Aquaculture, 312(1-4): $\quad 172-179$. https://doi.org/10.1016/j.aquaculture.2011 .01 .004

Bautista-teruel, M. N., \& Millamena, O. M. (1999). Diet development and evaluation for juvenile abalone, Haliotis asinina: protein and energy levels. Aquaculture, 178(1-2): $117-126$. https://doi.org/10.1016/S00448486(99)00121-0

Chalermwat, K., Szuster, B. W., \& Flaherty, M. (2003). Shellfish aquaculture in Thailand. Aquaculture Economics and Management, 7(3-4), 249-261. https://doi.org/10.1080/136573003093803 43

Chieu, H. D., Phuong, L. D., Duy, D. A., Tuan, B. M., \& Thoa, N. K. (2017). Aquaculture-Based enhancement and restoration of many-colored abalone resources ( Haliotis diversicolor Reeve , 1846 ) in Bach Long Vi National Marine Protected Area, Vietnam. Proccedings of the Symposium on Strategy for Fisheries Resources Enhancement in the Sotheast Asian Region, (July 2015).

Cho, S.-H., Park, J.-E., Kim, C.-I., Yoo, J.-H., Lee, S.-M., \& Choi, C.-Y. (2006). Effect of the various sources of dietary additives on growth, body composition and shell color of abalone Haliotis discus hannai. Journal of Aquaculture, 19(4), 275-280.

Cook, P. A. (2014). The Worldwide Abalone Industry. Modern Economy, 05(13), 1181-1186.

Cook, P. A. (2019). Worldwide Abalone Production Statistics. Journal of Shellfish Research, 38(2), 401-404. https://doi.org/10.2983/035.038.0222

Du, L., \& Niu, C. J. (2003). Effects of dietary substitution of soya bean meal for fish on consumption rate, growth and metabolism of juvenile giant freshwater prawn, Macrobrachium rosenbergii. Aquaculture Nutrition, $\quad 9(2)$ : 139-143. https://doi.org/10.1046/j.1365- 2095.2003.00239.x

FAO. (2017). GLOBEFISH - Information and Analysis on World Fish Trade.

Fermin, A. C. (2001). Tropical Abalone Culture in Philippines. (December), 6869.

Garcia-esquivel, Z., \& Felbeck, H. (2009). Comparative performance of juvenile red abalone, Haliotis rufescens, reared in laboratory with fresh kelp and balanced diets. Aquaculture Nutrition, 15(2): 209217 . https://doi.org/10.1111/j.13652095.2008.00585.x

Giri, N. A., Marzuqi, M., Astuti, N. W. W., Andriyanto, W., Rusdi, I., \& Andamari, R. (2015). Evaluasi bahan baku pakan dan pengembangan pakan buatan untuk budidaya pembesaran abalon (Haliotis squamata). Jurnal Riset Akuakultur, 10(3): $\quad 379-388$. http://dx.doi.org/10.15578/jra.10.3.2015.3 79-388

Giri, N. A., Marzuqi, M., Rusdi, I., \& Andriyanto, W. (2016). Formulasi pakan buatan dengan bahan baku rumput laut untuk pertumbuhan abalon Haliotis squamata. Jurnal Riset Akuakultur, 11(1), $75-83$.

http://dx.doi.org/10.15578/jra.11.1.2016.7 $5-83$

Hahn, K. . (1989). Handbook of culture of abalone and other marine gastropods. Florida: CRC Press.

Jang, B., Kim, P. Y., Kim, H. S., Lee, K. W., Kim, H. J., Choi, D. G., ... Han, H. (2018). Substitution effect of sea tangle (ST) (Laminaria japonica) with tunic of sea squirt (SS) (Halocynthia roretzi) in diet on growth and carcass composition of juvenile abalone (Haliotis discus, Reeve 1846). Aquaculture Nutrition, 24(1), 586593. https://doi.org/10.1111/anu.12593

Jarayabhand, P, Kojima, H., \& Menasveta, P. (1995). Embryonic and larval developments, and early growth of hatchery-produced abalone (Haliotis ovina Gmelin, 1971) seed. Warasan Waritchasat.

Jarayabhand, Padermsak, \& Paphavasit, N. (1996). A review of the culture of tropical abalone with special reference to Thailand. Aquaculture, 140(1-2), 159$168 . \quad$ https://doi.org/10.1016/00448486(95)01194-3 
Jung, W., Kim, H. S., Lee, K. W., Kim, Y. E., Choi, D. K., Jang, B., ... Joo, Y. (2016). Growth and body composition effects of tuna byproduct meal substituted for fish meal in the diet of juvenile abalone, Haliotis discus. Journal of the World Aquaculture Society, 47(1), 74-81. https://doi.org/10.1111/jwas.12255

Khotimah, F. H., Permana, G. N., Rusdi, I., \& Susanto, B. (2018). Pemeliharaan larva abalon Haliotis squamata dengan pemberian jenis pakan berbeda dalam bentuk tepung. 13(1), 39-46. http://dx.doi.org/10.15578/jra.13.1.2018.3 9-46

Koizumi, Y., \& Tsuji, Y. (2017). Abalone Haliotis spp. In Application of Recirculating Aquaculture Systems in Japan (pp. 175-211). Springer.

Mai, K., Mercer, J. P., \& Donlon, J. (1995). Comparative studies on the nutrition of two species of abalone, Haliotis tuberculata L . and Haliotis discus hannai Ino . IV . Optimum dietary protein level for growth. Aquaculture, 136(1-2), 165180. https://doi.org/10.1016/00448486(95)01041-6

Marzuqi, M., Rusdi, I., \& Susanto, B. (2012). Aplikasi pakan buatan pada pemeliharaan benih abalon ( Haliotis squamata ). Jurnal Riset Akuakultur, 7(2), 237-245. http://dx.doi.org/10.15578/jra.7.2.2012.23 7-245

Mosquiera. (1992). Abalone growth rates on an artificial diet. Austasia Aquaculture.

Myung, S. H., Jung, W., Kim, H. S., Kim, Y. E., Cho, S. H., Jwa, M. S., ... Kim, B. (2016). Effects of dietary substitution of fishmeal with the combined dry microalgae, Nannochloropsis oceanica (NO) biomass residue and casein on growth and body composition of juvenile abalone (Haliotis discus). Aquaculture Research, 47(1), 341-348. https://doi.org/10.1111/are.12562

Nel, A., Pletschke, B. I., Jones, C. L. W., Kemp, J., Robinson, G., \& Britz, P. J. (2017). Effects of kelp Ecklonia maxima inclusion in formulated feed on the growth, feed utilisation and gut microbiota of South African abalone Haliotis midae. African Journal of Marine Science, $39(2)$. https://doi.org/10.2989/1814232X.2017.1
338203

Nur, K. U., Adams, L., Stone, D., Savva, N., \& Adams, M. (2018). Comparison of three inert markers in measuring apparent nutrient digestibility of juvenile abalone under different culture condition and temperature regimes. IOP Conference Series: Earth and Environmental Science, 139(1), 12004. IOP Publishing.

Park, C.-J., \& Kim, S. Y. (2013). Abalone Aquaculture in Korea. Journal of Shellfish Research, 32(1), 17-19. https://doi.org/10.2983/035.032.0104

Rusdi, I., Rahmawati, R., Khotimah, F., Permana, G. N., Kurniawan, H., Susanto, B., \& Giri, N. A. (2020). Status Teknologi Budidaya Abalon Haliotis squamata. Gondol, Bali: Balai Besar Riset Budidaya Laut dan Penyuluhan Perikanan.

Setyono, D. E. D. (2010). Abalon: Teknik Pembenihan. Jakarta: Ikatan Sarjana Oseanologi Indonesia (ISOI).

Tung, C. H., \& Alfaro, A. C. (2011). Effect of dietary protein and temperature on the growth and health of juvenile New Zealand black-footed abalone (Haliotis iris). Aquaculture Research, 42(3), 366385. https://doi.org/10.1111/j.13652109.2010.02631.x

Uki, N., Kemuyama, A., \& Watanabe, T. (1985). Nutritional Evaluation of Several Protein Sources in Diets for Abalone Haliotis discus hannai. Bulletin of the Japanese Society of Scientific Fisheries, 51(11), 1835-1839.

Uki, N., \& Kikuchi, S. (1984). Regulation of maturation and spawning of an abalone, Haliotis (Gastropoda) by external environmental factors. Aquaculture, 39(1-4), 247-261. https://doi.org/10.1016/00448486(84)90270-9

Vandepeer, M., \& van Barneveld, R. (2005). The use of terrestrial nutrition principles and techniques to advance Australian abalone aquaculture. In Recent Advances in Animal Nutrition in Australia (Vol. 15, pp. 215-220).

Wu, F., \& Zhang, G. (2016). Pacific Abalone Farming in China: Recent Innovations and Challenges. Journal of Shellfish Research, $\quad 35(3)$ : 703-710. https://doi.org/10.2983/035.035.0317 
Media Akuatika : Jurnal Ilmiah Jurusan Budidaya Perairan. 2020. 5(3): 95-106.

Zhang, G., Que, H., Liu, X., \& Xu, H. (2004).

Abalone mariculture in China. Journal of

Shellfish Research, 23(4), 947-951. 